\title{
Digenean Parasites of Labrid Fishes (Labridae: Symphodus) from Turkish Coasts of the Black Sea: New Records
}

\author{
Türkay Öztürk' ${ }^{10}$, Arzu Güven ${ }^{1,2}$ (D)
}

Cite this article as: Öztürk, T., \& Güven, A. (2021). Digenean Parasites of Labrid Fishes (Labridae: Symphodus) from Turkish Coasts of the Black Sea. Aquatic Sciences and Engineering, 36(3), 126-132.

ORCID IDs of the author:

T.Ö. 0000-0001-5568-3214

A.G. $0000-0002-8220-5282$

${ }^{1}$ Sinop University, Faculty of Fisheries and Aquatic Sciences, Sinop, Turkey

${ }^{2}$ Malatya Turgut Özal University, Vahap Küçük Vocational High School,

Malatya, Turkey

Submitted:

11.12.2020

Revision Requested:

28.01.2021

Last Revision Received:

30.01.2021

Accepted:

31.01.2021

Online Published:

08.04.2021

Correspondence:

Türkay Öztürk

E-mail:

turkay.ozturk@gmail.com

(c) Copyright 2021 The Author(s)

Available online at

https://dergipark.org.tr/ase

\begin{abstract}
In the present study digenean parasite faunas of four labrid fishes, Symphodus tinca, S. rossali, S. cinereus and $S$. ocellatus were investigated and compared. A total of 52 fish specimens were caught on the Black Sea coast near Sinop, Turkey, over two years. Eight digenean species were found in the four labrid fishes. These are Helicometra fasciata, Gaevskajatrema perezi, Proctoeces maculatus, Phyllodistomum crenilabri, Galactosomum lacteum, Condylocotyla pilodora, Metadena pauli and Opecoelidae gen. sp. Each digenean species on their respective hosts were counted, their prevalence, mean intensity and abundance values were determined. While the maximum parasite diversity was found in S. tinca, S. ocellatus was infected with the fewest parasites. Total parasite abundance was significantly high in S. roissali, which was infected with four species. A close resemblance was observed in the digenean parasite faunas of $S$. tinca and $S$. roissali. The core, secondary, satellite, and rare species in the digenean parasite community of each host were determined. This study contains the first data on the digenean parasites of labrid fish on Turkish Black Sea coast. Phyllodistomum crenilabri and Metadena pauli are new parasite records in Turkish fish parasite fauna, while Condylocotyla pilodora is a new parasite record for the labrid fishes.
\end{abstract}

Keywords: Trematode, digenea, parasites, Symphodus spp., Black Sea

\section{INTRODUCTION}

The family Labridae is one of the large taxons of fish, comprising approximately 580 species in 82 genera and they are widely dispersed in tropical and temperate marine waters around the world (Hanel, Westneat, \& Sturmbauer, 2002). A total of 20 species of this family have been recorded from the Turkish Sea to date (Bilecenoğlu, Kaya, Cihangir, \& Çiçek, 2014). A total of 5 out of 8 species of this family, which inhabit the Black Sea, are the species of the Symphodus genus. The native habitats of the genus Symphodus are the coastal zones of the East Atlantic Ocean, the Mediterranean and the Black Sea. They are found to a depth of 1-50 m near rocks and eel-grass beds. Labrid fish are not target species commercially. However, labrid fish are often caught by fishermen that focus on fishing for other species (Choat \& Bellwood, 1998; Nelson, 2006).
Digenean parasites provide important information about the aquatic ecosystem since they have complex life cycles, during which several groups of marine animals are used as intermediate hosts. There are a lot of published data on digenean parasites of labrid fishes from the Mediterranean and Black Sea (Sey, 1970; Nikolaeva \& Solonchenko, 1970; Parukhin, Naidenova, \& Nikolaeva, 1971; Gaevskaya \& Solonchenko, 1989; Campos, Carbonell, \& Pellicer, 1990; Campos \& Carbonell, 1994; Sasal, Niquil, \& Bartoli, 1999; Korniychuk, 2001; Bartoli, Gibson, \& Bray, 2005; Gargouri, Elbohli, \& Maamouri, 2010; Radujkovic \& Sundic, 2014; Munoz \& Diaz, 2015).

To date, there have been many survey studies on digenean parasites in Turkey (Oğuz \& Bray, 2006; Akmırza, 2013; Tepe, Oğuz, \& Heckmann, 2014; Çınar, 2014; Öztürk \& Özer, 2016; Öztürk \& Güven, 
2020). On the other hand, there are no previous studies on the digenean parasite fauna of labrid fish on the Black Sea coast of Turkey.

The aim of this research study is to investigate digenean parasites of four labrid fishes collected from the Sinop coast of the Black Sea. This study is the first survey on digenean parasites of the labrid fishes on the Turkish Black Sea coast.

\section{MATERIALS AND METHODS}

The present study was carried out between May 2015 and April 2017. The fish specimens were sampled with gill nets by fisher-

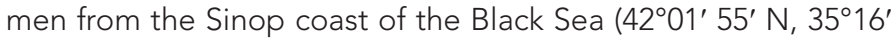
$36^{\prime}$ E). The caught fish were transported to the parasitology laboratory of the Faculty of Fisheries and Aquatic Sciences at Sinop University. A total of 52 specimens of the four labrid species, Symphodus tinca (27), S. cinereus (16), S. roissali (7) and S. ocellatus (2) were investigated for the digenean parasites. The fish were examined within $24 \mathrm{~h}$ of capture. At necropsy, the fishes were measured and weighed. Skin, fins, gills, eyes, brain, liver, stomach, intestine, kidney, urinary and gall bladder were examined under the dissecting microscope. The number of parasites was counted individually and the site of infection was recorded. Parasite specimens were studied in both alive and permanent preparations. For identification, the parasites were fixed in Bouin's fluid between slide and coverglass without pressure, stained with acetic carmine and mounted in Canada balsam. Permanent preparations were examined using a light microscope (Olympus microscope $\mathrm{B} \times 53)$ at magnification $\mathrm{X} 10$ and $\mathrm{X} 100$. The prevalence $(P, \%)$, mean intensity $(\mathrm{MI})$, and abundance $(A)$ values of each digenean parasites were calculated following the definitions of Bush, Lafferty, Lotz, \& Shostak, (1997). The standard deviation (SD) of the mean intensity was calculated. The Kruskal-Wallis test (Nonparametric ANOVA) was performed to compare the mean intensity values of digenean parasites in each fish host. The analyses were carried out using the computer programmes GraphPad Instat 3.0. P-values less than 0.05 were considered to be significant. The significance of the digenean parasite fauna was determined by using an abundance $(A)$ index according to the scale presented in Zander, Reimer, Barz, Dietel, \& Strohbach, (2000), as follows; $A>2$ : core species, $A=0.6-2$ : secondary species, $A=0.2-0.6$ : satellite species, $A<0.2$ : rare species. The Czekanowski-Sørensen Index (ICS, \%) was used to compare the digenean faunas of four Symphodus spp. (Sørensen, 1948).

\section{RESULTS AND DISCUSSION}

In the present study, a total of eight digenean parasite species including adults of Helicometra fasciata, Gaevskajatrema perezi, Proctoeces maculatus, Phyllodistomum crenilabri and metacercariae of Galactosomum lacteum, Condylocotyle pilodora, Metadena pauli and Opecoelidae gen. sp. were determined in four labrid fish (Table 1 and Figure 1).

Table 2 summarises the digenean parasite list with indications of prevalence (\%), mean intensity (MI), and abundance (A) values of identified digenean parasites in their respective fish hosts. Our results showed that $S$. tinca has the richest digenean fauna with 7 digenea species, but $S$. ocellatus was infected with only 2 digenea species (Table 2). In other words, the most diverse digenean fauna was found in S. tinca; $S$. ocellatus showed a low diversity with 2 species (Table 2). In this study, the parasite species richness observed in labrid fish may be related to sampling effort. Many more specimens of $S$. tinca (27 individuals) were examined, compared to $S$. ocellatus (2 individuals).

The overall mean intensity values of digenea parasite species varied significantly among the four labrid fish $(P<0.05)$. Overall, the highest prevalence and mean intensity values $(100 \%$ and 73.86) were found in S. roissali, which was infected with 4 digenea species. Galactosomum lacteum occurred only in S. tinca and Condylocotyle pilodora occurred only in S. cinereus (Table 2).

Metadena pauli was observed as a core species, but G. lacteum and C. pilodora were found as rare species (Table 2). Helicometra fasciata and G. perezi played the role of core in S.tinca and S. roissali. Proctoeces maculatus played the role of core, satellite or

Table 1. List of digenean parasite species identified in four labrid fish in the present study and their infection site (microhabitat)

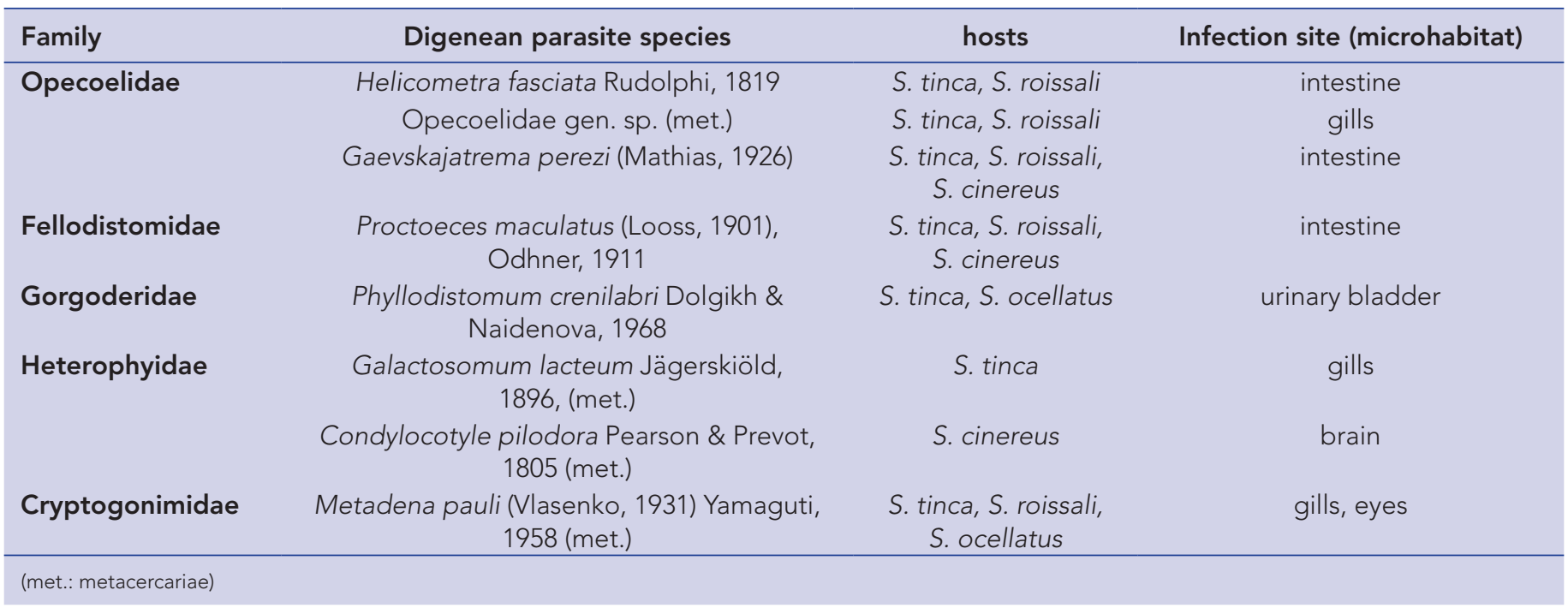




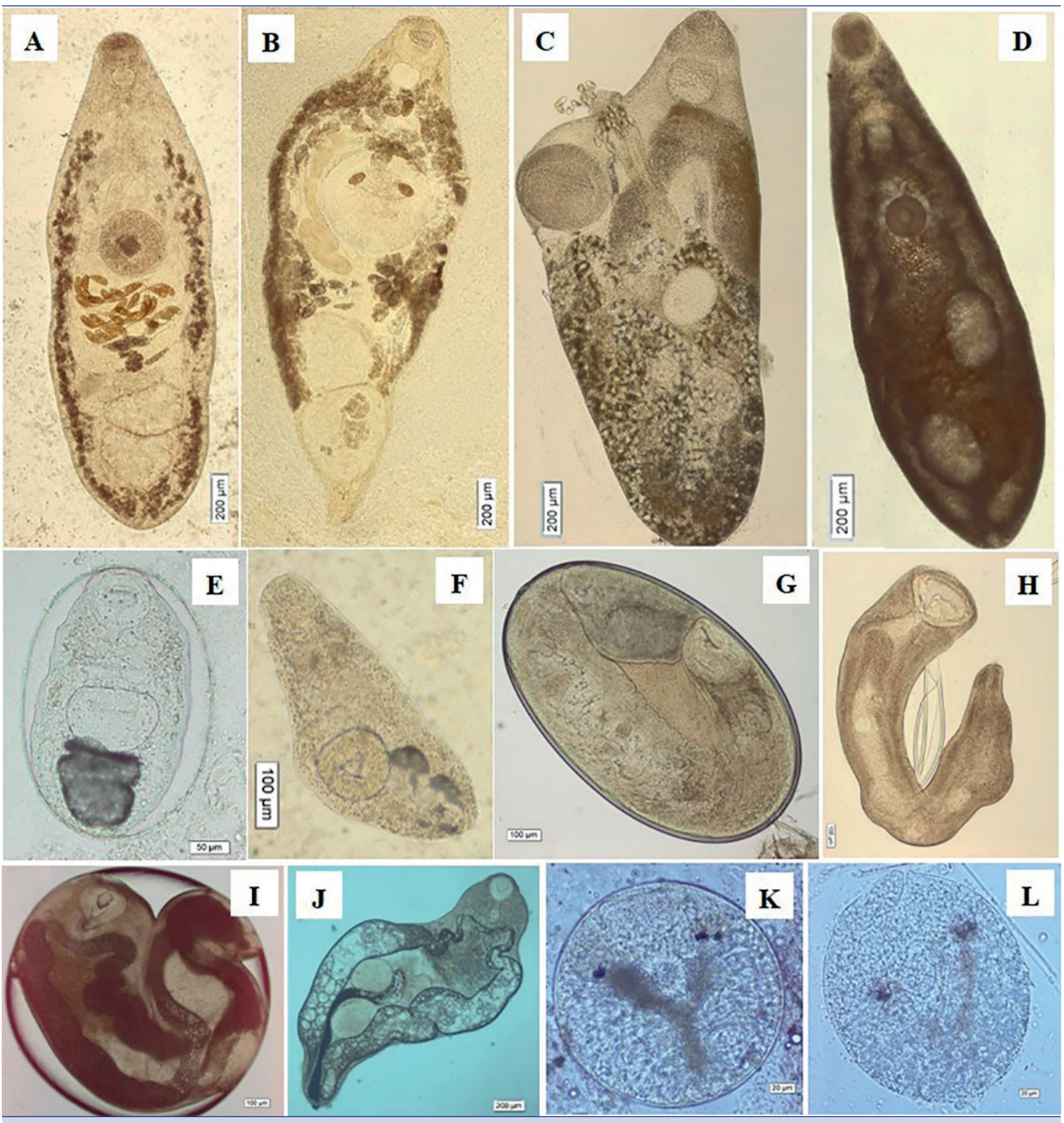

Figure 1. Digenean parasites identified in four labrid fish in this study (original), A) Helicometra fasciata, B) Gaevskajatrema perezi, C) Proctoeces maculatus, D) Phyllodistomum crenilabri, E) encysted metacercariae of Opecoelidae gen. sp., F) excysted metacercariae of Opecoelidae gen. sp. G) encysted metacercariae of Condocotyla pilodora, H) excysted metacercariae of C. pilodora, I) encysted metacercariae of Galactosomum lacteum, J) excysted metacercariae of G. lacteum, K) encysted metacercariae of Metadena pauli, L) excysted metacercariae of M. pauli. 


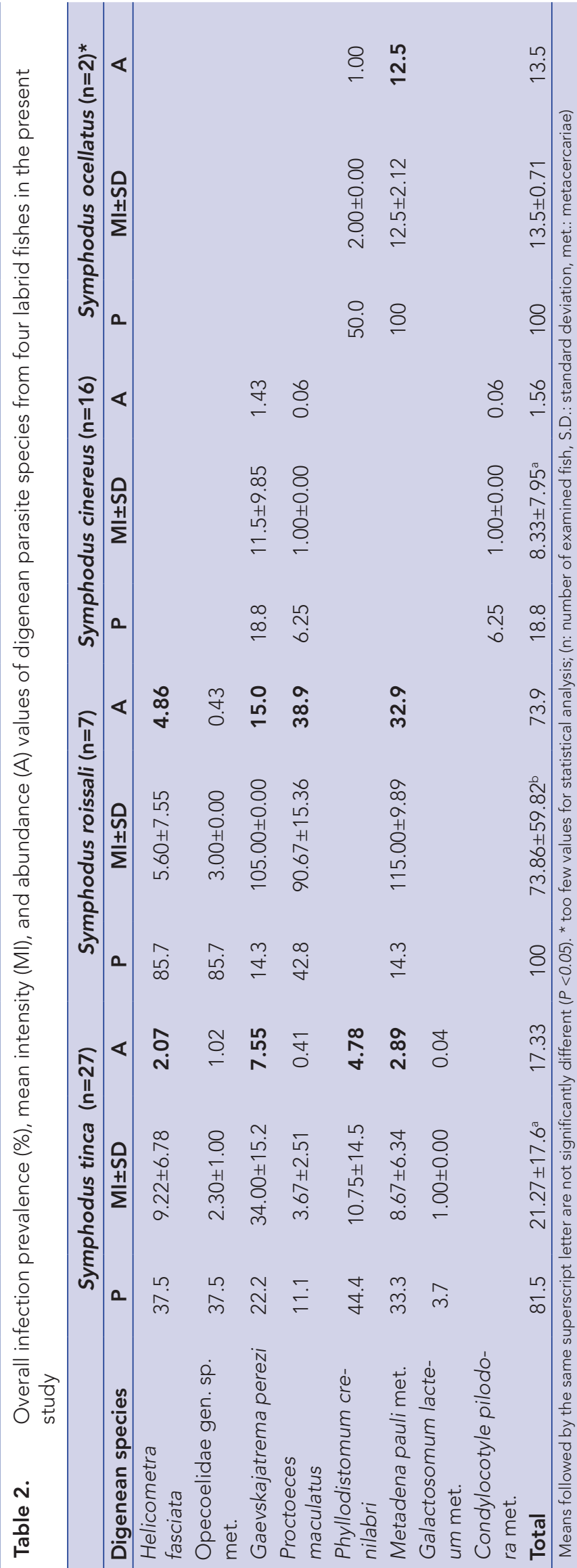

rare parasite depending on the host species. Phyllodistomum crenilabri was core in S. tinca, but secondary in S. ocellatus (Table 2). Moreover, all digenean species found in $S$. roissali were determined as core species (Table 2).

The digenean species composition and the digenean species richness of the four labrid fishes were found to be different in the present study. A close similarity was observed in the digenea fauna of S. tinca and S. roissali (ICS $=80.0 \%$ ) (Table 3). In this study, it was observed that the similarity among the digenean parasite fauna of the Symphodus species was low in general. Moreover, a similarity was not detected in digenea parasite fauna of two of the labrid fish, S. cinereus and S. ocellatus (Table 3).

Table 3. Czekanowski-Sorensen Index (\%) in digenean fauna of four labrid fish in the study area

\begin{tabular}{lcccc}
\hline & $\begin{array}{c}\text { S. } \\
\text { tinca }\end{array}$ & $\begin{array}{c}\text { S. } \\
\text { roissali }\end{array}$ & $\begin{array}{c}\text { S. } \\
\text { cinereus }\end{array}$ & $\begin{array}{c}\text { S. } \\
\text { ocellatus }\end{array}$ \\
\hline $\begin{array}{l}\text { S. tinca } \\
\text { S. }\end{array}$ & 100 & & & \\
roissali & 80.0 & 100 & & \\
$\begin{array}{l}\text { S. } \\
\text { cinereus }\end{array}$ & 44.4 & 57.1 & 100 & \\
$\begin{array}{l}\text { S. } \\
\text { ocellatus }\end{array}$ & 40.0 & 33.3 & 0.0 & 100 \\
& & & & \\
\end{tabular}

A high Czekanowski-Sorensen index, indicating a close similarity, was observed in the digenean parasite fauna of the $S$. tinca and $S$. roissali (80\%). But the digenea fauna of S. cinereus and S. ocellatus were not similar in the present study (Table 3). This may be related to the diet of the labrid hosts. The composition of the parasite fauna depends on many factors. The type of diet is one of them. This may be related with the diet of the labrid hosts. S. cinereus is carnivorous with a slight tendency toward omnivory, mostly consuming polychaetes, foraminiferans and decopod non-crustaceans (Fernandez, Freire, \& Gonzalez-Gurriaran, 1995). Whereas S. ocellatus is omnivorous, tending toward herbivory, mostly consume algae, and to a lesser extent bryozoans and hydroids (Kabasakal, 2001).

According to previous studies, it should be considered that the majority of the listed digenea species have been reported from S. tinca (Table 4).

Labridae is one of the most important families of marine fish with its biological diversity and ecological importance, and labrid fishes have distribution worldwide (Nelson, 2006). To date, a total of 134 records of digenean parasites have been enlisted from 127 labrid fish (Munoz \& Diaz, 2015). So far, 35 nominal digenean species have been reported in the four labrid fishes in the Mediterranean basin and Black Sea according to data of various authors (Table 4). Four species, H. fasciata, P.maculatus, P. acceptum and G. perezi, are typical digenean parasites of the labrid fishes and have also been reported in both basins (Table 4). Considering the number of digenea species reported in the four labrid fishes, except for the digenea species reported in both basins, it is noteworthy that the species diversity in the Mediterranean basin (19 species) is higher than from the Black Sea (9 species) (Table 4). The difference in di- 


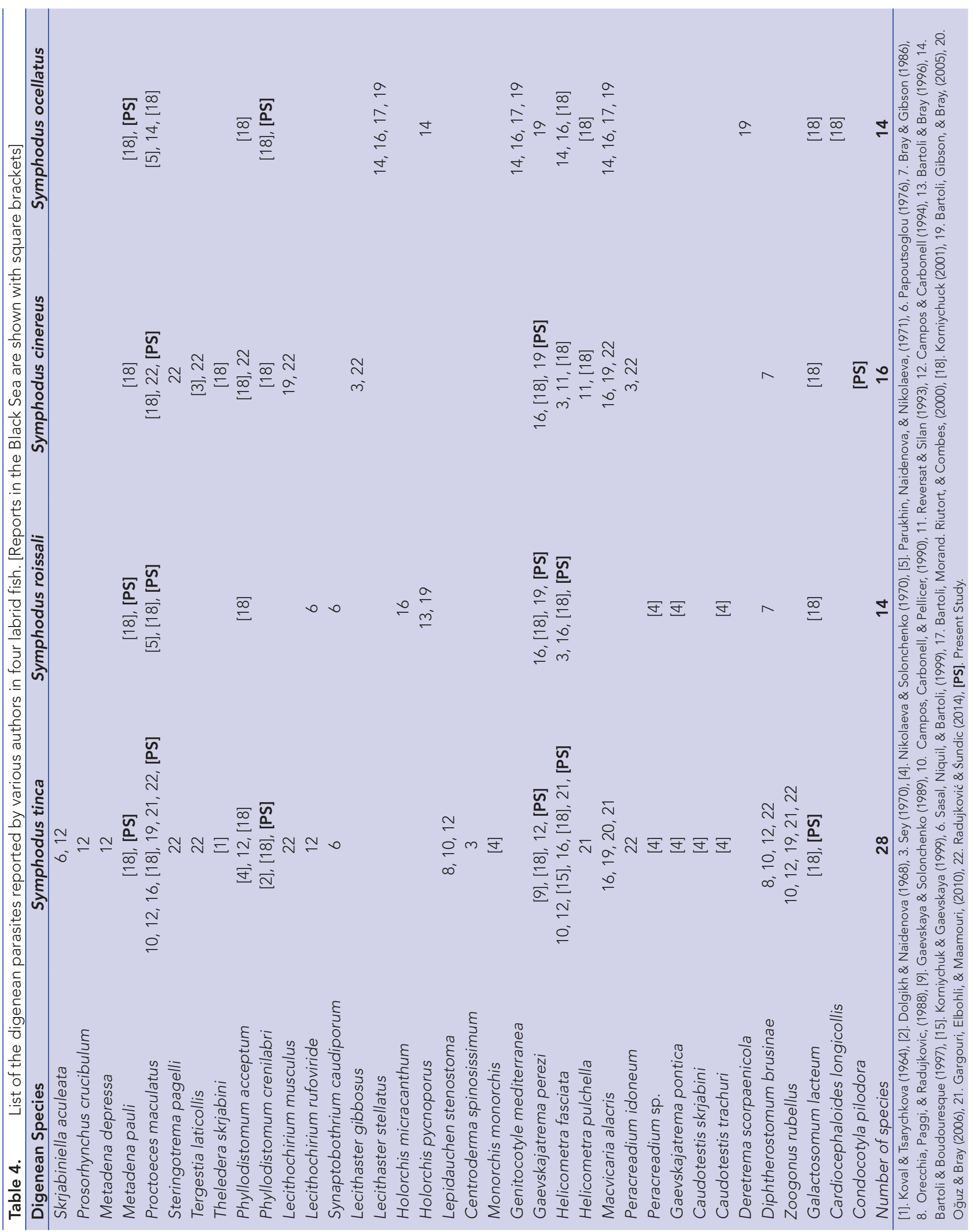


versity of digenean parasites reported from the Mediterranean basin and Black Sea may be related to the number of the intermediate hosts and the variation in physical and chemical parameters of the environment that can influence the host. So far, Condylocotyle pilodora has not been previously recorded in labrid fishes. It is remarkable that this digenean parasite is reported for the first time in labrid fish in the present investigation (Table 4). Thus, the number of digenean parasite species in the four labrid fishes reported in both basins has increased to 36 with the addition of C. pilodora.

\section{CONCLUSIONS}

This study revealed the first data on the digenean fauna of four fish species belonging to Sypmhodus genera in Turkish waters, and the data recovered in this paper contribute to the digenean parasites list of labrid fish inhabiting the Black Sea. In addition, these results contain some valuable knowledge, which can be used in future digenean parasite research.

Conflict of interest: The authors declare that they have no conflicts of interest.

Ethics Committee Approval: All applicable international, national and institutional guidelines for the care and use of animals were followed. The study protocol no. 19 of 13/07/2015 was approved by the Republic of Turkey, Sinop University Experimental Animals Local Ethics committee.

Acknowledgements: Authors are grateful to the Turkish Scientific and Technological Council (TUBITAK) for financial support. Some parts of this study were previously orally presented in an international symposium.

Financial disclosure: This study contains a part of the project that was supported financially by the Turkish Scientific and Technological Council (TUBITAK) with number of 2150224.

\section{REFERENCES}

Akmirza, A. (2013). Digenean trematodes of fish in the waters off Gökceada, the Aegean Sea, Turkey. Journal of the Black Sea / Mediterranean Environment, 19(3), 283-298. [CrossRef]

Bartoli, P. \& Bray, R.A. (1996). Description of three species of Holorchis Stossich, 1901 (Digenea: Lepocreadiidae) from marine fishes off Corsica. Systematic Parasitology, 35(2), 133-143. [CrossRef]

Bartoli, P. \& Boudouresque, C.F. (1997). Transmission failure of parasites (Digenea) in sites colonized by the recently introduced invasive alga Caulerpa taxifolia. Marine Ecology Progress Series, 154, 253-260. [CrossRef]

Bartoli, P., Morand. S., Riutort, J.J. \& Combes, C. (2000). Acquisition of parasites correlated with social rank and behavioural changes in fish species. Journal of Helminthology, 74(4), 289-293. [CrossRef]

Bartoli, P., Gibson, D.I. \& Bray, R.A. (2005). Digenean species diversity in teleost fish from a nature reserve of Corsica, France (Western Mediterranean), and a comparison with other Mediterranean regions. Journal of Natural History, 39(1), 47-70. [CrossRef]

Bilecenoğlu, M., Kaya, M., Cihangir, B. \& Çiçek, E. (2015). An updated checklist of the marine fishes of Turkey. Turkish Journal of Zoology, 38, 901-929. [CrossRef]

Bray, R.A. \& Gibson, D.I. (1986). The Zoogonidae (Digenea) of fishes from the north-east Atlantic. Bulletin of the British Museum (Natural History) Zoology, 51, 127-206. [CrossRef]
Bush, A.O., Lafferty, K.D., Lotz, J.M. \& Shostak, A.W. (1997). Parasitology meets ecology on its own terms: Margolis et al. revisited. Parasitology, 83, 575-583. [CrossRef]

Campos, A., Carbonell, E. \& Pellicer, M. (1990). Helmintofauna de Symphodus tinca (L.) y Labrus merula (L.) (Pisces: Labridae) del litoral Valenciano. 1. Trematoda. Revista Iberica de Parasitologia, 50(1-2), 37-42.

Campos, A. \& Carbonell, E. (1994). Parasite community diversity in two Mediterranean labrid fishes Symphodus tinca and Labrus merula. Journal of Fish Biology, 44(3), 409-413. [CrossRef]

Choat, J.H. \& Bellwood, D.R. (1998). Wrasses and parrotfishes. In: Paxton, J.R. and Eschmeyer, W.N. (Eds), Encyclopedia of fishes, (pp. 211-115). San Diego, Calif: Academic Press. ISBN: 0125476655 9780125476652

Çınar, M.E. (2014). Checklist of the phyla Platyhelminthes, Xenacoelomorpha, Nematoda, Acanthocephala, Myxozoa, Tardigrada, Cephalorhyncha, Nemertea, Echiura, Brachiopoda, Phoronida, Chaetognatha, and Chordata (Tunicata, Cephalochordata, and Hemichordata) from the coasts of Turkey. Turkish Journal of Zoology, 38(6), 698-722. [CrossRef]

Dolgikh, A.V. \& Naidenova, N.N. (1968). Some comments to trematodes of the family Gorgoderidae with description of a new species. Zoologicheskii Zhurnal, 47, 1717-1719 [In Russian].

Fernandez, L., Freire, J. \& Gonzalez-Gurriaran, E. (1995). Diel feding activity of demersal fishes in the Ria de Arousa (Galicia, NW Spain): an area of intense mussel raft culture. Cahiers de Biologie Marine, 36(2), 141-151.

Gaevskaya, A.V. \& Solonchenko, A.I. (1989). New data on the trematodes from the Black Sea fishes. Biologicheskie Nauki, 5, $43-47$ [In Russian].

Gargouri, L.B.A., Elbohli, S. \& Maamouri, F. (2010). Digenean diversity in labrid fish from the Bay of Bizerte in Tunisia. Journal of Helminthology, 84(1), 27-33. [CrossRef]

Hanel, R., Westneat, M.W. \& Sturmbauer, C. (2002). Phylogenetic relationships, evolution of broodcare behavior, and geographic speciation in the wrasse tribe Labrini. Journal of Molecular Evolution, 55(6), 776-789. [CrossRef]

Kabasakal, H. (2001). Description of the feeding morphology and the food habits of four sympatric labrids (Perciformes, Labridae) from south-eastern Aegean Sea, Turkey. Netherlands Journal of Zoology, 51(4), 439-455. [CrossRef]

Korniychuk, J.M. \& Gaevskaya, A.V. (1999). Reproductive strategy of trematode, Helicometra fasciata (Trematoda: Opecoelidae) as an index of favourability of its environment. Ekologiya Morya, 48, 42-47.

Korniychuck, J.M. (2001). Structure of the trematode fauna of the Black Sea labrid fishes (Pisces: Labridae). Ekologiya Morya, 59, 21-22.

Koval, V.P. \& Tsarychkova, D.B. (1964). A study of the trematodes of fishes from the Black Sea. Visnyk Kyyivs Koho Universytetu Seriya Biolohiyi, 6, 141-146.

Munoz, G. \& Diaz, P.E. (2015). Checklist of parasites of labrid fishes (Pisces: Labridae). Viña del Mar, Chile.

Nelson, J.S. (2006). Fishes of the World (4th Ed). John Wiley and Sons, USA. 601 p. ISBN: 0471250317

Nikolaeva, V.M. \& Solonchenko, A.I. (1970). Helminth fauna of some benthopelagic fish in the Black Sea. Biologiya. Morya, 20, 129-166 [In Russian].

Oğuz, M.C. \& Bray, R.A. (2006). Digenetic trematodes of some teleost fish off the Mudanya Coast (Sea of Marmara, Turkey). Helminthologia, 43(3), 161-167. [CrossRef]

Orecchia, P., Paggi, L., \& Radujkovic, B.M. (1988). Digeneans of fishes from the Adriatic Sea with a description of Lecithaster atherinae $\mathrm{n}$. sp. from Atherina (Hepsetia) boyeri. Parassitologia, 30, 225-229.

Öztürk, T. \& Özer, A. (2016). Digenean parasites of Atlantic horse mackerel (Trachurus trachurus) in the Turkish Black Sea coast. Ege Journal of Fisheries and Aquatic Sciences, 33(1), 35-40. [CrossRef] 
Öztürk, T. \& Güven, A. (2020). New Data on Digenean Parasites of Rusty Blenny, Parablennius sanguinolentus (Pallas, 1814) in the Black Sea. Sinop University Journal of Natural Sciences, 5(1), 26-37. [CrossRef]

Papoutsoglou, S.E. (1976). Metazoan parasites of fishes from Saronicos Gulf Athens-Greece. Thalassographica, 1, 69-102.

Parukhin, A.M., Naidenova, N.N. \& Nikolaeva, V.M. (1971). The parasite fauna of fishes caught in the Mediterranean Sea. In: Vodjanichky VA (ed). Expeditionary investigations in the Mediterranean Sea in MayJuly 1970 (A. Kovalevsky), pp. 64-87. Naukova Dumka, Russia.

Radujković, B.M. \& Śundic, D. (2014). Parasitic flatworms (Platyhelminthes: Monogenea, Digenea, Cestoda) of fish from Adriatic Sea. Natura Montenegrina, 13(1), 7-280.

Reversat, J. \& Silan, P. (1993). Comparative population biology of fish digenea: the case of three Helicometra (Trematoda: Opecoelidae) mesoparasites of marine teleosts in a Mediterranean lagoon. Annales de Parasitologie Humaine et Comparee, 68(3), 128-135. [CrossRef]

Sasal, P., Niquil, N. \& Bartoli, P. (1999). Community structure of digenean parasites of sparid and labrid fishes of the Mediterranean Sea: a new approach. Parasitology, 119(6), 635-648. [CrossRef]
Sey, O. (1970). Parasitic helminths occurring in Adriatic fishes, part II (Flukes and Tapeworms). ACTA Adriatica. 13, 3-15.

Sorensen, T.A. (1948). A new method of establishing groups of equal amplitude in plant sociology based on similarity of species content and its application to analysis of vegetation on danish commons. Biologiske Skrifter, 5, 1-34.

Tepe, Y., Oğuz, M.C. \& Heckmann, R.A. (2014). Digenean and cestode parasites of teleost fish from the Eastern Black Sea Region. Turkish Journal of Zoology, 38(2), 209-215. [CrossRef]

Zander, C.D., Reimer, L.W., Barz, K., Dietel, G. \& Strohbach, U. (2000). Parasite communities of the Salzhaff (northwest Mecklenberg, Baltic Sea). II. Guild communities, with special regard to snails, benthic crustaceans, and small-sized fish. Parasitology Research, 86(5), 359372. [CrossRef] 